\section{Order: Geophilomorpha}

Sp.1.

Material Examined: Madhya Pradesh: Betul (PBR), Kantawadi Village, Shahapur, near Machna River, 20.ii.2002, 2 exs., Coll. Dr. Y.N. Gupta; Hoshangabad (PBR), Nagduwari River, Mandai, 25.ii.2003, 1 ex., Coll. M.L. Koshta.

Sp.2.

Material Examined: Hoshangabad (PBR), Kesla, 11.ii.2003, 1 ex., Coll. Dr. Y.N. Gupta; Near Tawa Dam, Tawanagar, 13.ii.2004, 2 ex., Coll. Dr.Y.N. Gupta; Apsara Vihar, Panchmarhi, 12.ii.2003, 1 ex., Coll. M.L. Koshta; Takapar, Mandai, 26.ii.2003, 1 ex., Coll. M.L. Koshta.

\section{Class: Diplopoda}

Sp.1.

Material Examined: Chhatisgarh: Bilaspur, Sambhar Dasan Road, 8.vi.2004, 2 ex; Bastar, Rowghat Forest, 15.vii.2005, 1 ex.

\section{REFERENCES}

Ahmed, S. (1983). On the new records of centipedes (Scolopendromorpha: Scolopendridae) from Madhya Pradesh, India. Bulletin of Zoological Survey of India 5(1): 11-13.

Attems, C. (1930). Scolopendromorpha, Das Tierr., 54(2): 1- 308.

Bhatnagar, A. and R.J. Rao (2004). Biodiversity Conservation in the proposed Amarkantak Biosphere Reserve, Central India. Tiger paper 31(4): 10-16.

Gravely, F.H. (1910). The distribution of Oriental Scolopendridae. Records of Indian Museum 5(1): 161-172.

Jangi, B.S. and C.M.S. Dass (1984). Scolopendridae of Deccan. $J$. Scient. Indl. Res., 43(2): 27-54.

Khanna, V. (2001). A checklist of the Indian species of the centipede (Chilopoda: Scolopendromorpha). Annals of Forestry 9(2): 199-219.

Khanna, V. (2005). Trends in the distribution of Centipedes (Chilopoda: Scolopendromorpha: Scolopendridae and Cryptopidae) known from India. Annals of Forestry 13(1): 130-140.

\section{ACKNOWLEDGEMENTS}

The author is thankful to the Director, Zoological Survey of India, Kolkata for his encouragements and kind permission to undertake the studies, to Dr. Arun Kumar, Additional Director, Zoological Survey of India, Dehra Dun, for facilities and to Dr. Kailash Chandra, Joint Director and Officer-in-Charge, Central Regional Station, Zoological Survey of India, Jabalpur for placing the material at the disposal of the author.

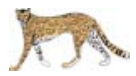

\section{AN UNUSUAL CLUTCH SIZE IN SARUS CRANE (GRUS ANTIGONE ANTIGONE) AT KODAIYA WETLAND, UTTAR PRADESH}

\section{Rajeev Chauhan ${ }^{1}$ and Devendra Kumar ${ }^{2}$}

${ }^{1}$ Secretary General, Society for Conservation of Nature, 576, Karamganj Punjabi Colony, Etawah, Uttar Pradesh 206001, India ${ }^{2}$ Divisional Forest Officer, Shrawasti, Uttar Pradesh, India

The Indian Sarus Crane (Grus antigone antigone) is the only resident species of Gruidae, south of the Himalayas. Apart from the Black-necked Crane (Grus nigricolis), it is the only species of crane breeding within the Indian subcontinent (Ali \& Ripley, 1980). One-third of the total Indian population of Sarus Cranes occur in the two districts of Etawah and Mainpuri in Uttar Pradesh (Sundar et al., 1999; Chauhan \& Kumar, 2000). The Wildlife Institute of India had established a field station in Etawah in 1999 to conduct a research project entitled "Impact of land use changes on habitat and ecology of Sarus Crane (Grus antigone) in India". We worked as volunteers for this project during which we made many observations. The normal clutch size in Sarus Crane is two with one egg clutch being infrequent as observed in Gujarat (Mukherjee et al., 2000) and three egg clutches were rare.

On 23 August 2001, we observed three nests with two eggs and two nests with one egg at Saifai and Kodaiya of district Etawah and Mainpuri. At Kodaiya, we found a nest situated in the middle of a wetland. The nest was built of Typha reeds and Eichornia and was surrounded by tall Typha reeds. It was difficult to verify the clutch size, but we observed the incubating female having difficulties with the nest. During her absence we observed that the nest had four eggs. Later, we learnt from the people of Rahin village in Etawah district that they had noticed a nest with three eggs in a neighbouring wetland. This is to report the first record of a four-egg clutch of Sarus Crane in the wild.

\section{REFERENCES}

Ali, S. and S.D. Ripley (1980). Handbook of Birds of India and Palistan Vol - 2. Megapods to Crab Plover. Oxford University Press. Chauhan, R. and D. Kumar (2000). A survey of Sarus Cranes (Grus antigone) in Etawah and Mainpuri districts, Uttar Pradesh, India. Technical Report, Society for Conservation of Nature, Etawah (U.P), 8 pp.

Mukherjee, A., V.C. Soni, C.K. Borad and B.M. Parasharya (2000). Nest and eggs of Sarus Crane (Grus antigone Linn.). Zoos' Print Journal 15(12): 375-385.

Sundar, K.S.G., J. Kaur and B.C. Chaudhury (1999). Distribution, general ecology and conservation status of the Indian Sarus Crane (Grus antigone antigone) in India survey 1998-1999. Wildlife Institute of India, Dehradun, 122pp.

\section{ACKnOWLedgement}

We are thankful to K.S. Gopi Sundar, SRF Wildlife Institute of India for literature and Ajay Kumar for field assistance.

Zoo Outreach Organisation; ww y jo Manuscript 1173; Received 23 March 2004; Finally accepted 06 June 2005; Date of publication 21 January 2006 